\title{
Geoportal of mining objects in Lesser Poland
}

\author{
Mateusz Jabłoński, Agnieszka Ochałek \\ AGH University of Science and Technology, Faculty of Mining Surveying and Environmental Engineering; \\ al.Mickiewicza 30,30-059 Krakow, Poland; e-mail: jablon@agh.edu.pl, aga.ochalek@gmail.com
}

(c) 2015 Authors. This is an open access publication, which can be used, distributed and reproduced in any medium according to the Creative Commons CC-BY 4.0 License requiring that the original work has been properly cited.

Southern Poland is a well developed mining area. There are copper and coal mines in Lower Silesia, huge coal deposits in Silesia and even oil in Subcarpathia. It is not well known that in Lesser Poland you can find almost all these deposits. Coal mines on west, one of the biggest in Europe zinc deposits, lots of working and closed limestone quarries in central part, oil wells on south and also old salt underground mines (Jureczka et al. 2011).

Geoportal MIIP is Lesser Poland Spatial Information System published in June 2011. It presents official spatial data among others from city and voivodeship, touristic and water structure. Moreover, anyone can add there another data. MIIP provides availability of WFS (Web Feature Service) and WMS (Web Map Service), both compatible with OGC (Open Geospatial Consortium) standards. One of the most interesting function is creating and editing users' own map and publishing it as interactive map on website (iMap). User can create his own composition and use any of published data, adding his own.
Polish mining industry is in crisis now. Media and environmental lobby constantly present it as a main reason of pollution problems. Additionally problems with taxes and low prices of coal deepen the collapse (Karnkowski 1993). Our responsibility is to show other citizens how mining is valuable for local community and for its landscape. To create geoportal of mining objects - closed and still operating ones - we used data from Central Base of Geological Data, Polish Geological Institute. On our portal you can find underground coal and salt mines, pit mines of zinc and limestone and oil wells.

The Geoportal of Mining in Lesser Poland is powered by mining section of Scientific Society KNGK Geoinformatyka.

\section{REFERENCES}

Jureczka J., Wołkowicz S., Smakowski T. \& Speczika S., 2011. Bilans perspektywicznych zasobów kopalin Polski wg stanu na 31 XII 2009 r. Państwowy Instytut Geologiczny - Państwowy Instytut Badawczy, Warszawa.

Karnkowski P., 1993. Złoża gazu ziemnego i ropy naftowej w Polsce. Cz. 2: Karpaty i Zapadlisko Przedkarpackie. Towarzystwo Geosynoptyków „Geos”, AGH, Kraków. 